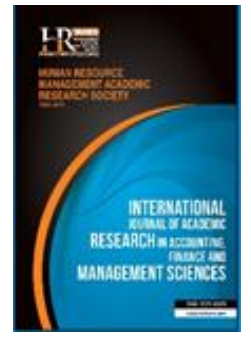

International Journal of Academic Research in Accounting, Finance and Management Sciences

Vol. 8, No.3, July 2018, pp. 163-177

E-ISSN: 2225-8329, P-ISSN: 2308-0337

(c) 2018 HRMARS

www.hrmars.com

To cite this article: Okwuraiwe, F. E., Ezenwaka, C., Mojekeh, M. O., Chiyem, O. (2018). Sales Force Turnover and Corporate Image of Selected Marketing Organizations in Anambra State, International Journal of Academic Research in Accounting, Finance and Management Sciences 8 (3): 163-177.

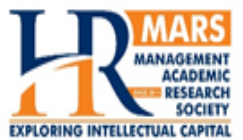

http://dx.doi.org/10.6007/IJARAFMS/v8-i3/4758 (DOI: 10.6007/IJARAFMS/v8-i3/4758)

\title{
Sales Force Turnover and Corporate Image of Selected Marketing Organizations in Anambra State
}

\author{
Frank E. OKWURAIWE ${ }^{1}$, Chika EZENWAKA ${ }^{2}$, Michael O. MOJEKEH ${ }^{3}$, Okorie CHIYEM $^{4}$ \\ ${ }^{1,4}$ Department of Marketing, Delta State Polytechnic, Ozoro, Delta State, Nigeria, \\ ${ }^{1}$ E-mail: Ofranky72@gmail.com, ${ }^{4}$ Email: Chiyemokorie.edu@gmail.com \\ 2,3Department of Marketing, Chukwuemeka Odumegwu Ojukwu University, Igbariam, Nigeria, \\ 3E-mail: mmojekeh2010@yahoo.com
}

\begin{abstract}
This study examined the effect of sales force turnover on the corporate image of selected organizations in Anambra State. The general objective of the study is to ascertain the effect of sales force turnover on corporate image of marketing organizations in Anambra State. The research adopted a survey design which made use of primary source data for analysis. The population of the study consists of 268 sales force personnel and 246 customers of selected marketing organizations. Based on the determined sample size of 514, copies of the questionnaire were distributed to respondents: 268 to companies' sales staff, 246 to companies' customers. Out of the total number of 268 copies of questionnaire distributed to staff, only 260 copies were returned well completed and fit for use in analyses. Out of this 246, 240 were well completed and used for analyses. The instrument of data collection consists of two sets of Likert-type, five-point scale self-administered questionnaire for staff and customers of selected marketing organizations of the study. The Pearson chi-square tests were used to test the five hypotheses of the study. The findings of the study showed that high sales force turnover has significant effect on the corporate image of marketing organizations in Anambra State; voluntary sales force turnover has significant effect on corporate image of marketing organizations in Anambra State. The findings of the study further revealed that long time retention of sales force has significant effect on the corporate image of marketing organization in Anambra State, and that customers' impressions of the sales force have significant effect on the corporate image of marketing organizations in Anambra State. Based on the findings of the study, it is recommended that marketing organizations in Anambra State should: invest more in the general welfare of their sales force to ensure employees stability and to work hard to keep the rate of voluntary sales force turnover to the barest minimum among others.
\end{abstract}

Key words Sales force, turnover, corporate image, marketing, organization

Received: 1 Sept $2018 \quad$ C The Authors 2018

Revised: 18 Sept 2018 Published by Human Resource Management Academic Research Society (www.hrmars.com)

Accepted: $\quad 30$ Sept 2018 This article is published under the Creative Commons Attribution (CC BY 4.0) license. Anyone may Published Online: 24 Oct 2018 reproduce, distribute, translate and create derivative works of this article (for both commercial and noncommercial purposes), subject to full attribution to the original publication and authors. The full terms of this license may be seen at: http://creativecommons.org/licences/by/4.0/legalcode

\section{Introduction}

Selling and sales management is a critical aspect of marketing organization and function that cannot be effectively executed without the sales force participation. Sales force personnel are staff of marketing organizations and firms that are directly concerned with initiating and consummating the selling process that ensures that goods and services of firms leave the shelves and offices, to get into the hands of customers and consumers for the satisfaction of their needs.

The activities of sales force come under the direct auspices of the personnel and selling departments of enterprises but are capable of affecting corporate image of companies and their public relations profiles and status. Sales force is therefore indispensable not only in addressing the selling and sales functions of 
companies and organizations but also in addressing their public relations challenges, which is the focus area of the study.

Osho (2010) states that public relations is an organization's effort to win the co-operation of groups of people that help an organization and its public, to adapt mutually to each other. Public-relations are all about the management of relationships through the tools of communication to build goodwill and harmony between an organization and its publics. It concerns itself with the public perceptions, expectations, opinion and attitudes, so that they may think well and act positively towards an organization.

Sales force remains one of the most productive resources available to a company. This is because sales force enacts sales that lead to the solvency and profitability of the company. Sales force is a component of the human resource capital of an organization that specialized in the selling of goods and services of that organization. They are employees of companies saddled with the field work of reaching out to various customer segments of these companies. In the face of increasingly challenging competitiveness and economic recession, the role of sales force employees in an enterprise, gains more weight and value than before, thus becoming the solution to the success of many companies. Arguably, this is the reason why managers and researchers have been showing long standing interest in identifying the conditions that promote employee job performance (Hui et al., 2007). Extant research has shown that employee intention regarding turnover has been considered to be an important antecedent to individual job performance (Palich et al., 1995). The implication of this is that sales force turnover intention or rate could affect individual staff performance, which in turn would affect firm's profitability and/or image or reputation.

Again, the strength or number of sales force can also affect sales as well as individual sales force performance. Thus, when sales force performance is increased, sales almost always increase (Tariq et al., 2013; Odetoyinbo, 2010). This is in the believe, that the more satisfied the sales force of a firm , everything being equal, the more the sales (in terms of quantity and revenue) it could make. This suggests that firms should keep on increasing the size of their sales force and not perchance, increasingly reducing the sales force. It is therefore expected that a company should maintain a reasonable and sizeable number of sales persons at its disposal, at a relatively stable rate, to gain good corporate image, maintain high market share, and increase sales volume and profitability. The front-line role of the sales force means that for many customers, the sales force is the company (Jobber and Lancaster, 2006).

Corporate image describes the manner in which a company or organization, its activities, and its products or services, are perceived by its various publics. It is about how a company or firm is perceived in the eyes of the general public and the image the company portrays. Employees of organizations are first and foremost, the most important publics of an organization often referred to in marketing as the organization's internal customers. The employees of an organization can affect the company's reputation or image. Employees who have a positive or negative work experience share it. Thus, attitudes of a company's employees often influence how it is perceived by its clients or external customers. As observed by Osho (2010) the reputation of an organization runs down easily if the workers are poorly paid, and badly treated. In fact, it is a matter of time, for such an organization to run into serious problem, total breakdown or staff always complaining. These are great hackers of corporate reputation...ultimately; this will affect the production of the organization, the quality of its products and services, market shares will dwindle, the profitability will nosedive drastically, which may lead to total breakdown and closure of the establishment.

Good corporate image should be craved for by every well-meaning company and the sales force could be final ambassadors of the company as they relate with the company's customers and the public at large. Image is generally a kind of unique, personal perception, state or position an individual or group has created or carved for itself. It can be "good" or "bad" as people usually referred to (Odetoyinbo, 2010). Thus, corporate image is here defined as the general opinion which a company creates for itself, with the view to gaining the positive disposition of its publics towards itself, products and services as well as, the perception which the various publics of the company hold about the company. In as much as it has been strongly suggested by past studies (Tariq et al., 2013; Osho, 2010) that increasing the sales force could increase sales volume and market share of business organizations, incessant sales force turnover could presumably affect the firms' image and performance negatively. It is being argued that high rate of sales force turnover could therefore lead to low sales and even firm's collapse. 


\subsection{Statement of the Problem}

As companies frontline employees, sales force staff are often regarded by many customers as the reflection of the company (Jobber and Lancasters, 2006). Where sales force turnover is high, the image of a company, as a stable and potentially successful corporate entity becomes doubtful and huge amount of money need to be expended on both public relations and staff recruitment practices, owing to high employee turnover (Nwokoye, 2005). Staff of every organization contributes to its corporate image (Osho, 2010). In the same vein, the corporate image of an organization can be undermined by absenteeism, lay-off and continuous changes of jobs to other organizations (Onwuchekwa, 1995). Many recent studies exist on the effect of labour turnover on corporate performance (see Hansknecht and Trevor, 2011; Holm, 2011; Shaw, 2011; Holtom et al.; 2008). Tariq et al. (2013) and Holm (2011) state that high workforce turnover have expected negative effect on corporate performance.

It has been alleged that private sector business organizations in Onitsha, and it's environ, especially, the small and medium enterprises (SMEs), are particularly prone to high rates of staff turnover and arguably impacting negatively on their corporate image. This study therefore empirically examined the phenomenon of sales force turnover dimensions, as perceived by staff and customers, and the effect on the corporate image, sales volume and profitability of Envoy Oil Limited and Golden Oil Industries Limited, all in Anambra State.

\subsection{Objectives of the Study}

The general objective of this study is to ascertain the effect of sales force turnover on corporate image of marketing organizations in Anambra State. The study specifically seeks to: assess the effect of voluntary sales force turnover; ascertain the effect of involuntary turnover animosity; and determine the effect of long time retention of sale force on the corporate image of companies in Anambra State.

\subsection{Hypotheses}

The following hypotheses were tested in the study:

- High sales force turnover has no significant effect on corporate image of marketing organizations in Anambra State.

- Voluntary sales force turnover has no significant effect on the corporate image of marketing organizations in Anambra State.

- Involuntary sales force turnover animosity has no significant effect on the corporate image of marketing organizations in Anambra State.

- Long time retention of sales force has no significant effect on the corporate image of marketing organizations in Anambra State.

This study covered the effect of sales force turnover on the corporate image of Envoy Oil Industries Limited, Onitsha and Golden Oil Industries Limited, Onitsha and life vegetable oil, Nnewi Anambra State, for the period between 2004 and 2014.Oil firms are chosen for the study because they make extensive use of sales force staff that engage in personal selling and directing marketing of their finished products.

\section{Conceptual Framework}

\subsection{Sales force}

The sales force is a company's frontline staff nearest to the customers. Arguably, the ideal sales force, the well-motivated and efficient sales staff, remains relatively long on the job and capable of delivering the goods and services of the company to meet the consumers' needs satisfactorily. As company's frontline staff, they are often perceived by many customers as the reflection of the company (Jobber and Lancaster, 2006). Sales force often forge close relationships with their customers and can influence their decisions to buy or not to buy the company's offerings and their turnover incur opportunity costs to their companies. Thus, human resources professionals continually work to control their companies' employee retention and turnover rates (Butali et al., 2003). Retention is the term given to keeping loyal employees on board with a company, while turnover refers to the rate at which a company loses existing employees and replace them with new ones. Shaw (2011), Hausknecht and Trevor (2011) and Holton, 
Mitchel, Lee and Eberly (2008) in their various studies made a distinction between voluntary turnover (workers quitting their being fired). Zeynep and Huckman (2008) argue that employee turnover in organizations has received substantial attention from both academics and managers. Much of this attention has been focused on understanding its causes. Implicit in this approach, is the assumption that turnover is driven by certain identifiable characteristics of workers, tasks, firms, and markets, and that, by developing policies to address these characteristics, managers might reduce the occurrence of sales force turnover in their respective organizations. Butali et al. (2013) arguing on the same line, state that understanding employee retention and turnover, and how each can be used to advantage can enhance a company's human resources policies and build a productive workforce.

Employees that stay long in organizations tend to have better job experiences; are more cost effective and more efficient on their jobs. As observed by Armstrong (2001), long-term employees generally have higher productivity and efficiency on the job than newer employees, due to their length of experience with the firm. Butali et al., (2013) state that as experienced workers are replaced by new hires, productivity can drop dramatically. Not only are new hires very unproductive compared to experienced workers, but trainers' productivity drops during training periods as well.

\subsection{Employee Turnover}

Theories concerning the effect of employee turnover on performance appear in several forms but they all rely on the premise that when members quit an organization it loses firm specific human capital and social capital, experiences a disruption to its routines and incurs various forms of search and training costs in connection with replacement (Hemsknecht and Trevor, 2011). Although authorities differ on the effects of turnover on organization, it is generally on performance. Zeynep and Huckman (2008) state that several studies suggest that turnover decreases operating performance and that low rates of turnover are preferable to high rates. Hom and Griffeth (1995) and Darmon (1990) emphasized on the indirect costs of turnover. The authors argued that much of the negative effect stems from the cost of turnover, such as those involved with severance and the recruitment and training of new employees. Firms may experience operational disruption following the departure of key employees (Mobley, 1982). This could be due to either the loss of the firm-specific that resides in departing employees or the loss of the social capital embedded in worker's relationship with each other and the organization Dess et al., (2001). Another source of indirect costs is the demoralization of employees who remain with the firm Steers et al.,(1981), this demoralization may be due to the loss of a respected colleague or the fact that turnover require additional work to be absorbed by remaining employees whose capacity is already stretched (Mowday and Porteir and Steers, 1982).

Turnover of sales force, whether voluntary turnover- an employee's decision to terminate the employment relationship with company or employer or involuntary turnover- a company's or employer's decision to terminate the employment relationship with an employee (Dess and Shaw, 2001), if not well managed, can affect the image of the company negatively. For many customers and other publics of companies, the employees, particularly the sales force, is the company. This view of the sales force can affect the company's image. Osho (2008) defines image as the subconscious impression a person has of an organization, institution or a person and such perception by the public will dictate their positive disposition or otherwise towards the products and services of the organization or firm.

\subsection{Voluntary Turnover}

This is a situation whereby an employee decides to terminate the employment relationship with company or employer. It describes a situation where an employee had to withdraw his or her services to an organization or company out of his or her own volition and with external pressure from the organization or company to do so (Dess and Shaw, 2001).

\subsection{Involuntary Turnover}

Involuntary turnover refers to a company's or employer's decision to terminate the employment relationship with an employee (Dess and Shaw, 2001). A situation whereby the action is not properly managed, it can affect the image of the company negatively. For many customers and other publics of 
companies, the employees, particularly the sales force, is the company. This view of the sales force can affect the company's image. Osho (2008) defines image as the subconscious impression a person has of an organization, institution or a person and such perception by the public will dictate their positive disposition or otherwise towards the products and services of the organization or firm.

\subsection{Corporate Image}

Corporate image describes the manner in which a company or organization, its activities, and its products or services, are perceived by its various publics. It is about how a company or firm is perceived in the eyes of the general public and the image the company portrays. Employees of organizations are first and foremost, the most important publics of an organization, often referred to in marketing as the organization's internal customers. The employees of an organization can affect the company's reputation or image. Employees who have a positive or negative work experience share it. Thus, attitudes of a company's employees often influence how it is perceived by its clients or external customers. As observed by Osho (2010) the reputation of an organization runs down easily if the workers are poorly paid, and badly treated. In fact, it is a matter of time, for such an organization run into serious problem, total breakdown or staff always complaining. These are great hackers of corporate reputation ultimately; this will affect the production of the organization, the quality of its products and services, market shares will dwindle, the profitability will nosedive drastically, which may lead to total breakdown and closure of the establishment.

Good corporate image should be craved for by every well-meaning company and the sales force could be final ambassadors of the company, as they relate with the company's customers and the public at large. Image is generally a kind of unique, personal perception, state or position an individual or group has created or craved for itself. It can be "good" or "bad" as people usually referred to (Odetoyinbo, 2010).

\subsection{Marketing Organization}

An organization comes into being when:

1. There are persons able to communicate with each other.

2. Who are willing to contribute action.

3. To accomplish a common purpose.

These elements are necessary and sufficient conditions initially and they are found in all such organizations (Nkem and Nkem, 1999). Organizations exist to service the internal and external interests of societies in which they belong. Any modern economy consists of households or consumers, business enterprises and non-business organizations, all of which constantly interacts within the context of a dynamic environment. The interaction resulting in the conception, development, production, distribution and consumption of goods and services whose major purpose is to satisfy human need (Agbonifoh et al, 1998). Marketing organization therefore, is an enterprise, which adopts the marketing concept in its structure operations, and functions (Nkem and Nkem, 1999), harnesses human and material resources, to ensure effective development, production, distribution and consumption of goods and services, for the satisfaction of human needs.

Some organizations use marketing research to achieve this; other use judgment, intuition, and marketing theories to give themselves sense of direction (lornem, 1990). The marketing concept entails identifying customers' needs, finding a product or service to satisfy these needs, and arranging for this product to be made and sold to the consumer, so that the whole operation is to the mutual benefit (profit) of both consumer and organization (Adirikaet al., 2001).

\section{Theoretical Framework}

The theoretical framework of the study is rooted in the Inequity Theory of Adam (1963). The theory is a motivational theory developed by J. Stacey Adams in the early 1960s. The theory holds that motivation can be affected through an individual's perception of fair treatment in the social exchanges that take place in work places when compared to other persons.

The Inequity Theory proposes that a person's motivation is based on what he or she considers fair, when compared to others. Individuals want to be compensated fairly for their contributions in their work places (outcomes they experienced is expected to match their inputs). A person's beliefs in regards to what 
is fair and what is not fair can affect their motivation, attitudes and behaviors and can lead to turnover when applied to the workplace. Inequity theory focuses on employee's reactions to work compensation as well as the employee's attempt to minimize any sense of unfairness that might result. Onwuchekwa (1995) states that this motivation theory concerns psychological reactions to feelings of inequity. The author defined inequality as feeling either under-or-over rewarded for one's contribution relative to the rewards of others in similar circumstances. Accordingly, individuals compare their own situations with others in similar situations, in terms of the contributions each makes and the rewards each derives.

When inequity is perceived, tension is felt in the victim and in the work environment. The greater the feeling of inequity, the greater the drive or motivation to reduce tension. This causes the employees concerned to attempt several options to awards achieving equity or fairness. Effort to attain equality or fairness can result in turnover. There is no doubt that most voluntary turnover are traceable to inequity or unfair compensation, as employees tend to incline towards greener pastures in terms of bigger and/or better pay. The implication of the inequity theory of motivation in the work place is that employers of labor should strive towards attaining equity in the compensation plans for employees. Lack of equity in reward to workers can trigger off incidences of high turnover, particularly voluntary turnover; an employee's decision to terminate the employment relationship. A principle of the inequity theory is based on the stimulus response that drives the organization to move away from unfavorable stimulus or condition. The Inequity Theory is linked to this study when it is considered that sales force turnover whether voluntary or involuntary, when considered unfair or occurs as result of injustice, is likely to lead to negative consequences on the corporate image and possibly, profitability of firms.

\subsection{Theoretical Exposition}

The theory of inequality specifies the conditions under which perceived inequality will arise and means by which it may be reduced or eliminated (Adams, 1981).

At the heart of inequality theory has the assumption that people pursue a balance between what the "invest" in a particular relationship (e.g. time, skills, effort) and the benefits they gain from it (such as status, appreciation, gratitude and pay (Adams, 1965). Every relationship strives towards achieving a balance, and distortion of this balance is expected to result in negative outcomes (Faris et al., 2004). Inequality in work relationships has been shown to be associated with lack of organizational commitment, manifesting in absenteeism and turnover, employee theft and burnout.

Individuals who perceived that they were not fairly treated or under rewarded will experience distress that may lead to certain actions to restore equity. To reverse or reduce perceived inequality the employee may resort to reducing his own effort. Some may try to influence their co-workers inputs through criticisms or even sabotage. Other may wish to withdraw emotionally or physically engage in absenteeism, tenderness or even quit the job entirely resulting voluntary turnover. Arguably, every employee wants to have an equitable exchange with the employer. Employees desire fair reward for fair labour and may resort to some negative actions to redress perceived inequity. As observed by Adams (1963), a large proportion of employment dissatisfaction, grievances, and industrial strikes appeared to result from employee perceived wage equities.

\subsection{Empirical and Review}

Osho (2010) examined the role of staff as internal publics of organizations cable of influencing the corporate image of any organization in Nigeria. The study adopted a qualitative approach in its analyses. The study explores the unique roles of staff in the public and private sectors of the economy and concludes that staff should be trained regularly, and oriented towards sound reputation for their organizations. The study further argues that staff could make or mar the corporate image or reputation of companies. The study reveals that the consciousness of every staff in Reputation management is crucial for the survival and sustenance of every organization via the internal and external publics of the organizations.

Javed et al. (2014) carried out a study that investigated the determinants of job satisfaction and its impact on employee performance and turnover Intentions. The study was conducted in the private as well as in public sector organizations in Bahawalpur City of Pakistan. The study among others observed that job satisfaction or lack of it hinges on productivity, accomplishing relationship between staff and management; 
indeed, the success of any organization depends on staff members who enjoy their jobs and feel rewarded by their efforts. The study aims at examined the job satisfaction levels of the employees and helped organizations to know about the elements that influence job satisfaction.

The study is a descriptive research, and self-administered questionnaire were circulated to a sample of 200 respondents, out of which 150 copies were properly filled and returned. The results or the data analysis showed significant association of employee empowerment, workplace environment, job loyalty and job performance with job satisfaction. Furthermore, the study showed a significant negative relationship between job satisfaction and turnover intention. The findings also demonstrated that there is no significant relationship of turnover intention with employee empowerment and job performance.

The study further shows that job dissatisfaction could cause employees to move away from their jobs, search for new jobs, or change their existing job and careers. It also shows that the degree of organizational loyalty of employee is higher when employee job satisfaction increased. The study also shows that job satisfaction has impact on job performance, according to the study, job performance (JP) contribute $14 \%$ to job satisfaction (IS). It shows that level of job satisfaction and motivation affect the employee's productivity. The higher performers demand attractive package from the employers, but job performance is negatively related to the turnover intention. JP contributes $9 \%$ to turnover intention but the regression result shows that performance has no significant relation with turnover intention because performance $(P)$ is greater than 0.5 .

The study is not without limitations. First the study considered only few factors of job satisfaction like job performance, employee empowerment, job loyalty, turnover intention, and workplace environment. Secondly, the survey was conducted with small sample which needs to be increased to enable a more indepth understanding of the most important determinant of job satisfaction and employee turnover at a more generalized level. Thirdly, the data for the study was collected from a particular group of people (employees in Bahawalpur). The study did not consider variables like reward and recognition, training and development, and organizational commitment which need to be discussed for further understanding of job satisfaction.

In a related study, Zeynep et al. (2008) examined the impact of employee turnover on operating performance in settings that require high levels of knowledge exploitation. The study was conducted in the United States of American. Using 48 months of turnover data from U.S. stores of a major retail chain, the study discovered that, on average, employee turnover is associated with decreased performance, as measured by profit margin and customer service. The study focused its empirical analysis on the retail industry. Reason for this includes the fact that retail accounts for a substantial portion of employment in the United States. The study quoted the National retail federation by stating that, in 2003 retailers in the United States employed more than 23 million people, nearly one out of every five American workers. Again, most retailers operate with high levels of employee turnover which makes retailing an important context in which to study the turnover phenomenon. Finally, retail provides a setting in which performance depend on the repetition of known tasks rather than on innovation.

Many studies reviewed in this study considered the causes and effects of turnover on business or firm's performance, none of the study reviewed focused on the causes and/or effects of sales force turnover on businesses in Nigeria or South-East, Nigeria for that matter. This creates serious gaps in research and knowledge while the study is poised to address.

\section{Methodology of research}

The study adopted descriptive and exploratory research design through primary data source. The research instruments were two sets of five-scale Likert-type of questionnaires, for the sales force and customers of the selected companies. Each set of questionnaire consists of 25 closed choice questions derived from the variables of the study as well as demography of respondents. The population of the study consists of staff and customers of the selected companies namely: Envoy Oil Limited, Onitsha Golden Oil Industries Limited, Onitsha, and Life Vegetable Oil Limited, Nnewi. To determine the sales force (staff) population of the study, a pilot survey was conducted using Purposive sampling technique, through which copies of self-administered questionnaire were administered to Management and other staff of the 
selected companies. The outcome of the survey of the selected firms show the number of sales force for the selected companies stood at 268.

Table 1. Number of Employees of selected companies in Onitsha

\begin{tabular}{|c|c|c|c|c|c|c|c|c|}
\hline S/N & Name of company & $\begin{array}{l}\text { No of } \\
\text { Staff }\end{array}$ & $\begin{array}{l}\text { Mgt } \\
\text { staff }\end{array}$ & $\begin{array}{c}\text { Senior } \\
\text { admin staff }\end{array}$ & $\begin{array}{c}\text { Senior } \\
\text { technical staff }\end{array}$ & $\begin{array}{l}\text { Factory } \\
\text { workers }\end{array}$ & $\begin{array}{l}\text { Sales } \\
\text { force }\end{array}$ & Others \\
\hline 1 & Envoy Oil Industries & 306 & 17 & 43 & 18 & 66 & 85 & 77 \\
\hline 2 & Golden oil Industries Ltd & 499 & 22 & 82 & 86 & 126 & 93 & 90 \\
\hline \multirow[t]{2}{*}{3} & Life Vegetable Oil Ltd. Nnewi & 482 & 30 & 70 & 60 & 170 & 90 & 62 \\
\hline & Total & 1117 & 69 & 195 & 164 & 362 & 268 & 229 \\
\hline
\end{tabular}

Source: Personnel Department of selected companies, October, 2016.

Table 2. Result of Customers Responses

\begin{tabular}{|c|l|ccc|}
\hline S/N & \multicolumn{1}{|c|}{ Name of Company } & Yes & No & Grand Total \\
\hline 1 & Envoy Oil Limited, Onitsha & 20 & 5 & 25 \\
2 & Gold Oil Industries Limited, Onitsha & 30 & 5 & 35 \\
3 & Life Vegetable Oil Ltd. Nnewi & 30 & 10 & 40 \\
\hline & Total & 80 & 20 & 100 \\
\hline
\end{tabular}

Source: Pilot Survey conducted in October, 2016.

Based on the results of the pilot study, a total of 80 respondents claimed to be regular customers of the selected companies, while 20 respondents claimed they were not regular customers of the selected companies. These represent $80 \%$ of the pilot survey in favor, while $20 \%$ is against.

Based on this, the Cochran formula was applied to determine the population of the customers of the selected companies:

$N=Z^{2}(P Q$

Where:

$\mathrm{n}=$ the desire population size

$\mathrm{Z}=$ confidence limit of $95 \%$ or 1.96

$\mathrm{P}=$ probability of regular patronage $=80 \%$

$Q=$ probability of irregular patronage $=20 \%$

$\mathrm{N}=(1.96)^{2} \times(0.8 \times 0.2)=245.8624$, approximate to 246. $(0.05)^{2}$

Therefore, the population of the study was 514 consisting of: 268 for sales force staff and 246 for customers of the selected companies. The population of study is small (less than 1000), and 514 is the sample size.

\subsection{Model Specification}

Chi-square tests were conducted to test the hypotheses of the study. Data collected from the administered questionnaire to staff of the selected companies were used to test the independent variable $(x)$ high sales force turnover; low sales force turnover; turnover animosity; long time sales force retention; customers impression of sales force and the dependent variable $(\mathrm{Y})$ positive business corporate image.

The design has a model specification and operationalization of variables as follows; positive business corporate image is a function of high sales force turnover, voluntary sales force turnover, involuntary sales force turnover animosity, long time sales force retention and customers impressions of sales force.

Positive business corporate image $(\mathrm{Y})=$ dependent variable and high and low sales force turnover, turnover animosity, sales force retention and customers impressions of sale force $=$ independent variables.

$Y=f(x)$

$Y=f(x 1, x 2, x 3, x 4, x 5)$ 


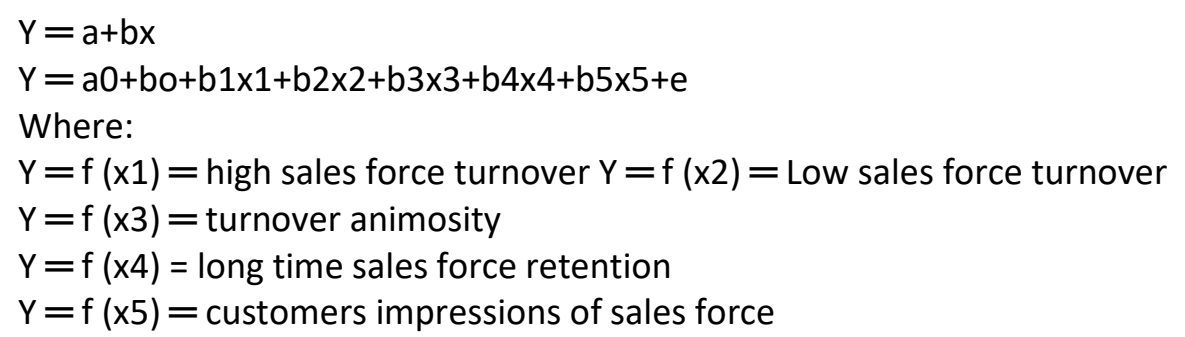

\subsection{Analysis of data and discussion of findings}

The total population of the study is 514 consisting of 268 sales force personnel and 246 companies customers. A total of 514copies of the questionnaire were distributed to respondents: 268 to companies' sales staff, 246 to companies' customers. Out of the total number of 268 copies of questionnaire distributed to staff, only 260 copies were returned well completed and fit for use in analyses. Out of this 246 , distributed to companies' customers, 240 were well completed and used for analyses. The male had a total number of 314 or $63 \%$ while the female had a total number of 186 or $37 \%$.

Test of first Hypothesis of the Study: High sales force turnover has no significant effect on corporate image of marketing organizations in Anambra State.

Table 3. Chi Square Test Result for Hypothesis One

\begin{tabular}{|lccc|}
\hline & Value & Df & Asymp. Sig. (2-sided) \\
\hline Pearson Chi-Square & $157.119^{a}$ & 16 & .000 \\
Likelihood Ratio & 174.002 & 16 & .000 \\
Linear-by-Linear Association & 6.509 & 1 & .011 \\
\hline N of Valid Cases & 1300 & & \\
\hline
\end{tabular}

Research Question 2: How Significant is the effect of voluntary sales force turnover on the corporate image of marketing organization in Anambra State?

Table 4. Responses of each Respondent to Research Question 2

\begin{tabular}{|c|c|c|c|c|c|c|c|}
\hline & \multicolumn{5}{|c|}{ Response } & \multirow[b]{2}{*}{ Total } \\
\hline & & $\begin{array}{c}\text { strongly } \\
\text { agree }\end{array}$ & agree & Undecided & disagree & $\begin{array}{l}\text { strongly } \\
\text { disagree }\end{array}$ & \\
\hline \multirow{6}{*}{$\begin{array}{l}\text { Effect of } \\
\text { voluntary } \\
\text { sales force } \\
\text { turnover }\end{array}$} & $\begin{array}{l}\text { Voluntary sales force turnover } \\
\text { could lead to loss of goodwill from } \\
\text { customers }\end{array}$ & 80 & 150 & 10 & 20 & 0 & 260 \\
\hline & $\begin{array}{l}\text { Voluntary sales force turnover } \\
\text { could lead to loss of beneficial } \\
\text { customer-company relationship.... }\end{array}$ & 100 & 100 & 25 & 35 & 0 & 260 \\
\hline & $\begin{array}{l}\text { Voluntary turnover of skilled staff } \\
\text { of a company could impact } \\
\text { negatively on the overall corporate } \\
\text { image of that company }\end{array}$ & 120 & 90 & 5 & 20 & 25 & 260 \\
\hline & $\begin{array}{l}\text { High incidence of voluntary } \\
\text { turnover could create doubts on } \\
\text { public perception of the company's } \\
\text { corporate image }\end{array}$ & 125 & 105 & 15 & 10 & 5 & 260 \\
\hline & $\begin{array}{l}\text { Voluntary turnover could } \\
\text { undetermined the confidence of } \\
\text { remaining staff of the company as } \\
\text { a high profile organization } \\
\text { Total }\end{array}$ & 70 & 100 & 25 & 30 & 35 & 260 \\
\hline & Total & 495 & 545 & 80 & 115 & 65 & 1300 \\
\hline
\end{tabular}


Table 4 above cross tabulates the effect of voluntary sales force turnover on the responses of the staffs. Each respondent responded under each category of the Likert scale from strongly agree to strongly disagree in respect of questionnaire items $6,7,8,9$ and 10 . Thus, responses to the question to the effect that "Voluntary sales force turnover could lead to loss of good will from customers" are as follows: Strongly Agree=80; Agree=150; Uncertain=10; Disagree $=20$ and Strongly Disagree $=0$.

The total respondents are 260.Responses to the effect that "Voluntary sales force turnover could lead to loss of beneficial customer-company relationship through loss of contact of personalized skills of the departed staff impacting negatively on the corporate image of a company" shows: Strongly Agree=100; Agree $=100$; Uncertain $=25$; Disagree $=35$ and Strongly Disagree $=0$. Total respondents to this questionnaire item are 260. To the questionnaire item that states: "Voluntary turnover of skilled staff of a company could impact negatively on the overall corporate image of that company," are as follows: Strongly Agree $=120$ Agree $=90$ Uncertain $=5$ Disagree $=20$ and Strongly Disagree $=25$. Total respondents are 260. Responses to the questionnaire item that states: "High incidence of voluntary turnover could create doubts on public perception of the company's corporate image" shows: Strongly Agree=125; Agree=105; Uncertain= 15; Disagree $=10$ and Strongly Disagree $=5$. Total respondents to this questionnaire item are 260 . Responses to the questionnaire item which states: "Voluntary turnover could undermine the confidence of remaining staff of the company as a high profile organization" are as follows: Strongly Agree $=70$ Agree $=100$ Uncertain $=25$ Disagree $=30$ and Strongly Disagree $=35$. Total respondents are 260 . Cumulative responses to the five questionnaire items under the effect of voluntary sales force turnover is 1300 .

Test of the second hypothesis of the Study:

$\mathbf{H}_{0}$ : Voluntary sales force turnover has no effect on the corporate image of marketing organizations in Anambra state.

Test outcome of the test of this hypothesis is presented below:

Table 5. Chi-Square Test Result for Hypothesis Number Two

\begin{tabular}{|lccc|}
\hline & Value & Df & Asymp. Sig. (2-sided) \\
\hline Pearson Chi-Square & $159.554^{\mathrm{a}}$ & 16 & .000 \\
Likelihood Ratio & 174.465 & 16 & .000 \\
Linear-by-Linear Association & 16.315 & 1 & .000 \\
\hline N of Valid Cases & 1300 & & \\
\hline
\end{tabular}

This table shows us the $p$-value of the chi square test which helps us to either reject or accept the null hypothesis. If the $p$-value is less than 0.05 , we reject the null hypothesis otherwise, we accept. In this analysis, taking a look at the table 16 above, we will observe that the p-value for the chi square is 0.000 which is a value less than 0.05 , hence, we reject the null hypothesis and conclude that voluntary sales force turnover has an effect on the corporate image of marketing organizations in Anambra state.

This table shows us the $p$-value of the chi square test which helps us to either reject or accept the null hypothesis. If the $p$-value is less than 0.05 , we reject the null hypothesis otherwise, we accept. In this analysis, taking a look at the table below, we will observe that the $p$-value for the chi square is 0.000 which is a value less than 0.05 , hence, we reject the null hypothesis and conclude that voluntary sales force turnover has an effect on the corporate image of marketing organizations in Anambra state.

Research Question 3: Does voluntary turnover animosity has any significant effect on the corporate image of companies in Anambra State?

Response to this research question is presented in table 11 as follows: 
Table 6. Responses of each Respondent to Research Question 3

\begin{tabular}{|c|c|c|c|c|c|c|c|}
\hline & \multicolumn{5}{|c|}{ Response } & \multirow[b]{2}{*}{ Total } \\
\hline & & $\begin{array}{c}\text { strongly } \\
\text { agree }\end{array}$ & agree & Undecided & disagree & $\begin{array}{l}\text { strongly } \\
\text { disagree }\end{array}$ & \\
\hline $\begin{array}{ll}\text { Effect of } & \text { s } \\
\text { sales } & c \\
\text { force } & 0 \\
\text { turnover } & r\end{array}$ & $\begin{array}{l}\text { sales force turnover animosity } \\
\text { could tarnish the corporate image } \\
\text { of a company in the eyes of the } \\
\text { remaining staff }\end{array}$ & 80 & 100 & 30 & 30 & 20 & 260 \\
\hline $\begin{array}{r}\text { animosity } \mathrm{T} \\
\text { in }\end{array}$ & $\begin{array}{l}\text { Turnover animosity could lead to } \\
\text { increase public relation costs }\end{array}$ & 90 & 130 & 5 & 5 & 30 & 260 \\
\hline & $\begin{array}{l}\text { Turnover animosity could lower } \\
\text { company's performance through } \\
\text { loss of public goodwill }\end{array}$ & 100 & 110 & 15 & 5 & 30 & 260 \\
\hline & $\begin{array}{l}\text { Sales force animosity could damage } \\
\text { company corporate reputation in } \\
\text { the eyes of customers of the } \\
\text { company }\end{array}$ & 80 & 100 & 40 & 30 & 10 & 260 \\
\hline & $\begin{array}{l}\text { Sales force animosity could create } \\
\text { crisis of confidence between a } \\
\text { company and its remaining staff }\end{array}$ & 140 & 70 & 30 & 10 & 10 & 260 \\
\hline Total & & 490 & 510 & 120 & 80 & 100 & 1300 \\
\hline
\end{tabular}

\subsection{Discussion of Findings}

The general objective of this study is to ascertain the effect of sales force turnover on the corporate image of marketing organizations in Anambra State.

To achieve these objectives of the study, the effects of high sales force turnover; voluntary sales force turnover; sales force turnover animosity; long time sales force retention and customers' impressions of sales force as independent variables of the study on corporate image of marketing organizations in Anambra state as dependent variable, were examined.

To establish this fact empirically, Pearson Chi-square was used to test the five alternative hypotheses of the study based on both staff respondents and customer respondents' responses during data collection.

Chi-square test of the first hypothesis of the study which states that, "Sales force turnover has no significant effect on the corporate image of marketing organizations in Anambra State" for staff responses, showed a significance value of 0.000 which is less than 0.05 . This led to the rejection of the null hypothesis and the acceptance of alternative hypothesis which states that, "Sales force turnover has significant effect on the corporate image of marketing organizations in Anambra State." Also, analysis of data on customer responses to the same hypothesis showed a significant value of 0.000 which is less than 0.05 . This equally, led to the rejection of the afore-stated null hypothesis and the acceptance of the alternative hypothesis. The verdict therefore, is that high sales force turnover has a significant effect on the corporate image of marketing organizations in Anambra State. This outcome of analysis showed that the first objective of the study which sought to examined the effect of high sales force turnover on the corporate image of marketing organizations in Anambra state was positively achieved.

No doubt, high incidence of sales force turnover could provoke public opinion that could affect the corporate image of an organization. Staff of organizations play important role in promoting and managing the reputation or image of the organizations. This assertion is collaborated by Osho (2010) which statesthat; staff of various organizations is the internal publics who serve as the most important publics. This is hinged on the capacity of the staff of organizations to make the realization of corporate goals and objectives achievable. The Osho (2010) further states that, the reputation of an organization runs down easily if the workers are poorly paid, and badly treated. In fact, it is a matter of time, for such an organization to run into serious problem, total breakdown or staff always complaining. There are great hackers of corporate image. 
The second null hypothesis of the study which states that, "Voluntary sales force turnover has no significant effect on the corporate image of marketing organizations in Anambra State," based on the staff responses, recorded a chi-square test significance value of 0.000 which is less than 0.05 . This resulted in the rejection of the null hypothesis and the acceptance of the alternative hypothesis which states that, "Voluntary sales force turnover has significant effect on the corporate image of marketing organizations in Anambra State." In the same vein, customer responses test of the second hypothesis of the study, showed also, a significant value of 0.000 which is less than 0.05 . This consequently resulted in the rejection of the second null hypothesis of the study and the acceptance of the second alternative hypothesis of the study. This also indicated that the second objective of the study which sought to assess the effect of voluntary sales force turnover on the corporate image of marketing organizations in Anambra State, was positively attained.

That voluntary turnover could have effect on corporate image of organizations is inferred from Holm (2012) which states that voluntary turnover has expected negative effect on performance of organizations. Furthermore, Holm (2012) maintains that theories concerning the effect of voluntary turnover on performance appear in several forms but they rely on the premise that when members quit an organization it loses firm specific human capital and social capital, experiences a disruption to its routines and incurs various forms of search and training costs in connection with replacement which ultimately could affect the organization's corporate image. Shaw, Gupta and Delery (2005) posit that there is a significant, negative relationship between voluntary turnover and workforce performance. There is no doubt that such negative relationship would extend to the corporate image of the organization.

The third null hypothesis tested states that, "Involuntary sales force turnover animosity has no significant effect on the corporate image of marketing organizations in Anambra State." Chi-square test of this null hypothesis both for staff and customer responses showed the significance value of 0.000 which is less than 0.05 respectively. The null hypothesis was therefore rejected in favor of the alternative hypothesis which states that, "Involuntary sales force turnover animosity has significant effect on corporate image of marketing organizations in Anambra State." This also means that the third objective of the study which sought to ascertain the effect of involuntary turnover animosity on the corporate image of companies in Anambra State was positively ascertained.

Turnover animosity can have negative effect on company's reputation or image. Butali et al. (2013) affirmed that staff turnover can have negative effect on an organization. It can lead to a loss of productivity, profitability, corporate knowledge, and skills and competencies. In addition, staff turnover is not just an issue for the organizations experiencing staff turnover; it can also cause headaches for external organizations communicating with them. Turnover animosity is a veritable threat to corporate image of organizations.

Results from the chi-square tests of the fourth null hypothesis for both staff and customer respondents of the study which states that, "Iong time retention of sales force has no significant effect on the corporate image of marketing organizations in Anambra State" showed a significant value of 0.000 which again is less than 0.05 respectively. For this reason, the null hypothesis was rejected and the alternative hypothesis which states that, "Long time retention of sales force has a significant effect on corporate image of marketing organizations in Anambra State," was accepted. This equally indicated that the fourth objective of the study which sought to determine the effect of long time retention of sale force on the corporate image of companies in Anambra State was attained in the positive. Butali et al., (2013) agree that retaining employees carries obvious advantages. In the same vein, Armstrong (2001) observed that long-term employees generally have higher productivity and efficiency on the job than newer employees, due to their length experience with the firm. Loyal employees also improve operational processes and train incoming employees. All these go a long way to impacting positively on the overall image of the organization. Again, Cole (2000) maintained that loyal employees can also be loyal customers and avoid word-of-mouth advertisers in certain cases. Especially for manufacturers and sellers of consumer products, loyal employees entire families sometimes purchase and use the products based on mutual goodwill and company's positive corporate image.

The fifth null hypothesis of the study for both staff and customers tested with Pearson chi-square analysis showed a result of 0.000 significant values which is less than 0.05 respectively. With this result, the 
null hypothesis which states that, "Customers' impressions of the sales force have no significant effect on the corporate image of marketing organizations in Anambra State" was rejected in favor of the alternative hypothesis which states that, "Customers' impression of the sales force have significance effect on the corporate image of marketing organizations in Anambra State." This is in agreement with the position of Jobber and Lancaster (2006). Thus, as company's frontline staff, sales force is often perceived by many customers as the reflection of the company. This is also, indicative that the fifth objective of the study which sought to ascertain the effect of customers' impressions of sales force turn over on the corporate image of companies in Anambra State was positively affirmed.

In all it must be emphasized that several studies suggest that staff turnover decreases operating performance and that low rates of staff turnover are preferred to high rates (2008).

\subsection{Summary of Findings}

1. Sales force turnover has significant effect on the corporate image of a firm.

2. Voluntary sales force turnover has significant effect on the corporate image of a firm.

3. Involuntary sales force animosity has significant effect on the corporate image of a firm.

4. Long time retention of sales force has significant effect on the corporate image of a firm.

5. Customers' impressions of the sales force have significant effect on the corporate image of a firm.

\section{Conclusions}

Employee turnover in an organization is critical determinant and predictor of organization's performance and profitability. Thus managers and the academia have paid much attention to understanding the immediate and remote causes of employees' turnover and it consequences on organizational performance. In considering the turnover question, the common assumption is that turnover is driven by certain identifiable characteristics of workers, tasks, firms, and markets, and that, by developing policies to address these characteristics, managers might reduce if not eradicate completely, the occurrence of employees turnover. Be that as it may, this study focused on the effect of sales force turnover on corporate image of marketing organizations. The major implication of this study is that employees turnover, whether voluntary or involuntary implies multidimensional effects; its effect on the corporate image of organizations being just an aspect of its multidimensional nature.

Suffice it to state that incidence of sales force turnover; turnover animosity and customers/ impressions of company's sales force could hurt corporate image of organizations and that organizations should do well to minimize the occurrence of involuntary employee turnover. For organizations to benefit from the social capital factor, deliberate attempt should be made to maximize employees and talents retention.

\section{Recommendations}

Based on the findings of the study, the following recommendations hereby suggested:

1. Marketing organizations in Anambra State should invest more in the general welfare of their sales force to ensure employees profile stability.

2. Marketing Organizations in Anambra State should work hard to keep the rate of voluntary sales force turnover to its barest minimum to benefit from staff wealth of experience and by extension, staff goodwill.

3. Marketing organizations in Anambra State should articulate policies that could check involuntary turnover animosity that could hurt the corporate image of their organizations.

4. Marketing organizations in Anambra State should articulate proactive human resource motivation strategies that would engender long term retention of employees in their organizations.

5. Marketing organizations in Anambra state should cultivate the loyalty of their sales force to win their goodwill as ambassadors of their organizations. 


\section{References}

1. Adams, J.S. (1963). Toward an understanding of inequity, Journal of Abnormal psychology, 67, 422-436.

2. Adams, J.S. (1965). Inequity in social exchange in Berkowitz, L. (Ed.), Advances in experimental social psychology vol. 2, New York: Academic Press.

3. Adams, J.S. (1981). This week's citation classic, citation classic, 43, 245.

4. Adeniran, E. A. (2010). Managing in Nigeria conflicts and reputation with strategic behavioral change and communication, Image Maker, Public Relations Journal, 2(9), 49-58.

5. Busch, P. S. and Houston M. J. (1985).Marketing strategic foundations. Homewood, Illinois: Richard .D. Irwin, Inc.

6. Butali, N.D., Wesang'ula, P.N and Manuli, L.C. (2013).Effects of staff turnover on the employee performance of work at NasirideMuliro University of Science and Technology, International Journal of Human Resource Studies, 3(1), 1-8.

7. Dess, G.G and Shaw J.D (2001).Voluntary turnover, social capital, and organizational performance, Academy of Management Review, 28 (3), 446-456.

8. Envoy Oil Industries Limited (2015) Envoy oil Itd http://www.envoyoilltd.com/10/10/2015. Golden Oil Industries Limited (2013). Golden oil Itd Onitsha. http://www.Goldenoiltd.com/14/12/2013.

9. Hansknetcht, T.P. and Trevor, C.O, (2011). Collective turnover at the group, unit and organizational levels: evidence, issues, and implications, Journal of Management, 16(4), 343-366.

10.Herberg, F., Mansner, B. and Synderman, B.B. (1959). The motivation to work, New York: Wiley and Sons, Inc.

11. Holm, J. R (2012). The effects on performance of voluntary and involuntary labour turnover in an evolutionary signaling model, department of business and management, Aalborg university, 1-26.

12. Holm, J.R. (2011)."Adaptive solution through selection: how populations of firms adapt to changing environments", PhD Thesis, Aalborg University.

13.Holtom, B.C. Mitchell, T.R., Lee, T.W. and Eberly, M.B. (2008).Turnover and retention research: a glance at the past, a chosen review of the Present, and a Venture into the Future, The Academy of Management Annals, 2(1), 231-274.

14.Hom, P and Gritteth, R. (1993). Employee turnover, Cincinatti Ohio: South- Western Publishing.

15.Javed, M., Balouch, R. and Hassan, F. (201).Determinants of job satisfaction and its impact on employee performance and turnover intention, International Journal of Learning and Development, 4 (2), 120-140.

16.Jobber, .D. and Lancaster G. (2006). Selling and sales management, $7^{\text {th }}$ Edition, Harlow, England: Prentice Hall.

17.Karch, G.E. and Peters, M. (2017). The impact of employee uniforms on job satisfaction in the hospitality industry, Journal of Hotel and Business Management. 6 (1), 1-6.

18.Kumari, N. (2011). Jon satisfaction at the workplace, European Journal of Business Management, (34).11-31.

19.Leonard, J.S. and Levine, D.I. (2006). The effect of diversity on turnover: A large case study, Industrial and Labor Relations Review, 50 (4), 547-572.

20.Lornem, D. (1990).The functions of the field sales force, marketing theory for practitioners. A book of readings. Ed. Olukunlelyanda, Nigerian Institute of Management, Ibadan: Heinmann Educational Books (Nigeria) Ltd.

21.Mobley, W. (1982). Employee turnover: causes, consequences and control, reading. MA: AddisonWesley.

22.Mowday, R, Foster, I. and Steers, R. (1982). Employee organization linkages: the psychology of commitment, absenteeism, and turnover, New York, Academic Press.

23.Nwokoye, .I.M. (2005). Employee training and career development in organizations a study of Anambra State House of Assembly, (ANHA), Awka, Unpublished M.Sc. Dissertation, Department of Government and Public Administration, Faculty of Imo State University, Owerri.

24.Odetoyinbo, A. (2010). Integrity and image management of secretaries and personal assistants, Public Relations Journal, 2(9), 16-33. 
25.Okpara, G. S. (2002). Contemporary marketing: topical and tropicalized. Enugu: John Jacob's Classic Publishers Ltd.

26.Ongori, H. (2007). A review of the literature on employee turnover, African Journal of Business Management, 049-054.

27.Onwuchekwe, C.I (1995). Personnel management, Awka: Goshen Publishers.

28.Osho, S .A. (2010). The role of staff in reputation management in the public and private sectors of the company: reputation management in public private sector, Image Maker Public Relations Journals, 2(9), 1-15.

29.Osho, S.A. (2008). Public relations policy: planning and strategies, Abeokuta: Ess-oh Consult publications.

30.Shaw, J. D., Gupta,N. and Delery, J. E. (2005). Alternative conceptualizations of the relationship between voluntary turnover and organizational performance, Academy of Management Journal, 48(1), 5068.

31.Shaw, J.D. (2011). Turnover rates and organizational performance: review, critique, and research agenda, Organizational Psychology Review, 1(3), 187-213.

32.Shin, I., Hur, W. and Kang, S. (2016). Employees' perception of corporate social responsibility and job performance: A sequential mediation model, Journal of Sustainability, 8 (493), 1-12.

33.Steers, Rad Mowday, R, (1981). Employee turnover and post decision accommodation processes, Organizational Behavior Research, 3,235-281.

34.Tariq, M.N., Ramzan .M. and Riaz .A. (2013).The impact of employee turnover on the efficiency of the organization, Interdisciplinary Journal of Contemporary Research In Business, 4(9), 700-711.

35.Taris, T.W., Vanttorn, J.E., Schaufeli; W.B. and Schreurs, P.J.G. (2004). Inequity, Burnout and psychological withdrawal aulong teachers: A dynamic exchange model, anxiety, stress and coping, 17 (1), 103-127.

36.Zeynep, T and Huckman, R .S. (2008).Managing the impact of employee turnover on performance: the role of process conformance" Organization Science, 19(1), 56-68. 